\title{
Brexit
}

\section{Wightman en het soevereine recht om lid van de EU te blijven}

\author{
Mr. dr. Armin Cuyvers*
}

Wightman bevestigt het unilaterale, soevereine recht van een lidstaat om een kennisgeving van uittreding in te trekken. Deze bijdrage bespreekt zowel dit recht op intrekking als de eventuele grenzen aan dit recht, waaronder wellicht misbruik van recht.

Hvf 10 December 2018, zaak C-621/18, Wightman, ECLI:EU:C:2018:999.

\section{Inleiding}

Ja, het mag. Een kennisgeving tot uittreding onder artikel 50 Verdrag betreffende de Europese Unie (VEU) kan eenzijdig worden ingetrokken. Dit is de korte samenvatting van Wightman, en ook de belangrijkste uitkomst voor het bijna surrealistische eindspel van Brexit. ${ }^{1}$ Tot het allerlaatste moment voor uittreding kan het Verenigd Koninkrijk (VK) eenzijdig de kennisgeving tot uittreding van 29 maart 2017 intrekken en daarmee het huidige lidmaatschap van de Europese Unie (EU) behouden. Furidisch gezien zou Brexit daarmee in één klap van de baan zijn. Politiek gezien zouden wij echter, ook na intrekking, nog steeds in een nieuwe, en nogal ongemakkelijke, werkelijkheid leven, zowel in de 28 EU-lidstaten als in het VK zelf.

De relevantie van Wightman gaat echter verder dan Brexit. Vragen rondom toetreding en uittreding raken inherent aan de constitutionele kern van de EU. Zowel de uitkomst als de motivering van het voltallige Hof van Justitie in Wightman geven daarmee verdere puzzelstukjes voor de zich ontwikkelende constitutionele mozaiek van de EU. ${ }^{2}$ Deze bijdrage gaat daarom eerst in op het soevereine recht op intrekking zoals erkend in Wightman. Vervolgens wordt stilgestaan bij twee nog openstaande vragen: welke grenzen stelt EU-recht aan intrekking, en hoe kunnen deze grenzen gehandhaafd worden? Kan het VK het intrekkingsrecht bijvoorbeeld misbruiken door de kennisgeving in te trekken en direct weer in te dienen, wie mag dit bepalen, en wat zouden de rechtsgevolgen zijn?

Relevante feiten en achtergrond geding Op 29 maart 2017 gaf het VK aan de Europese Raad kennis van zijn voornemen de EU te verlaten. Met deze kennisgeving werd voor het eerst artikel $50 \mathrm{VEU}$ in werking gesteld. De beperkte tekst van artikel $50 \mathrm{VEU}$ gaf echter geen expliciet antwoord op de vraag of een kennisgeving ingetrokken kon worden. ${ }^{3} \mathrm{Al}$ op 19 december 2017 stapte daarom een groep leden van het Schotse parlement, het Lagerhuis en het Europees Parlement naar de Schotse rechter met het verzoek te oordelen over de mogelijkheid van intrekking. ${ }^{4}$ De Court of Session, Inner House (de hoogste Schotse rechter in deze zaak) stelde vervolgens prejudiciële vragen: kon het VK de kennisgeving eenzijdig intrekken en daarmee het EUlidmaatschap onder dezelfde voorwaarden behouden? In een mooi voorbeeld van een (nogal) open dialoog gaf de Court of Session daarbij fijntjes aan dat, aangezien Schotse rechters al zelden prejudiciële vragen stellen 'it would be disappointing if a rare request for assistance were to be met with a negative response'. ${ }^{5}$

Deze angst van de Schotse rechter bleek ongegrond. Op 18 oktober 2018 wees de president van het Hof van Justitie het verzoek van de Court of Session toe om de ver-
* Mr. dr. A. (Armin) Cuyvers is universitair hoofddocent Europees Recht aan het Europa Instituut Leiden Law School. Deze bijdrage is mede gebaseerd op een Engelstalige bijdrage die in Common Market Law Review zal verschijnen. Ik dank de reviewers voor hun zeer nuttige commentaren en ideeën.

1. HvJ 10 december 2018, zaak C-621/18, Wightman, ECLI:EU:C: 2018:999. Zie verder ook S.C.G. van den Bogaert en A. Cuyvers, 'Brexit Blues: They still haven't found what they're looking for ...', NJB 2019, nr. 19, p. 1388-1397.
2. Zie ook H. de Waele, 'Herroepbaarheid van de Brexit-notificatie, The Good, the Bad, and the Ugly', NJB 2019, nr. 6, p. 392.

3. Zie ook A. Cuyvers 'Artikel 50 VEU en Brexit: de juridische contouren voor een politiek drama', NtEr 2016/7, p. 221.

4. Voor de verwijzingsbeschikking zie www.scotcourts.gov.uk/docs/ default-source/cos-general-docs/pdf-docs-for-opinions/ 2018csih62.pdf?sfvrsn=0 (hierna: verwijzingsbeschikking).

5. Verwijzingsbeschikking, punt 30. 
snelde procedure te gebruiken. ${ }^{6}$ De conclusie van advocaat-generaal Campos Sánchez-Bordona volgde op 4 december 2018, waarna het Hof van Justitie al op 8 december 2018 arrest wees, drie dagen voor de geplande Brexit-stemming in het Lagerhuis. ${ }^{7}$

\section{Conclusie van advocaat-generaal Campos \\ Sánchez-Bordona}

De advocaat-generaal concludeert dat eenzijdige intrekking mogelijk is. Interessant is dat hij zijn argumentatie begint met een analyse van internationaal publiekrecht en artikel $50 \mathrm{VEU}$ interpreteert als een lex specialis van dit meer algemene kader. ${ }^{8}$ In plaats van de gebruikelijke nadruk op de unieke en autonome aard van de EUrechtsorde benadrukt de advocaat-generaal hiermee juist de internationaalrechtelijke wortels van de EU. Binnen het internationaal publiekrecht focust de advocaat-generaal op artikel 68 Weens verdragenverdrag (WVV) dat stelt dat een kennisgeving betreffende terugtrekking uit een verdrag te allen tijde kan worden herroepen, voordat de terugtrekking van kracht is geworden.

Artikel $68 \mathrm{WVV}$ vormt geen regel van internationaal gewoonterecht maar heeft wel voldoende normatieve kracht om dienst te doen als 'een grote inspiratiebron', mede omdat artikel $50 \mathrm{VEU}$ gebaseerd is op artikel 65 tot en met $68 \mathrm{WVV}$ en 'de EU een tussen staten gesloten internationaal verdrag vormt en tegelijkertijd ook de oprichtingsakte van een internationale organisatie'. ${ }^{10}$

Bij de interpretatie van het Europese recht zelf benadrukt de advocaat-generaal de eenzijdige en soevereine aard van de keuze om uit de EU te stappen. ${ }^{11}$ Daarnaast beargumenteert de advocaat-generaal dat een kennisgeving tot uittreding vernietigd kan worden, bijvoorbeeld door een nationale rechter, wat noodzakelijkerwijs zou moeten leiden tot intrekking van deze kennisgeving. ${ }^{12}$ Verder wijst de advocaat-generaal op de plicht onder artikel 4 lid 2 VEU om de constitutionele identiteit van een lidstaat te erkennen en op het feit dat artikel 50 VEU geen recht geeft om de facto een lidstaat tegen de eigen wil uit de EU te zetten. ${ }^{13}$

6. Beschikking van de president van 19 oktober 2018, Wightman (zaak C-621/18, ECLI:EU:C:2018:851).

7. Op 10 december 2018 besloot toenmalig premier May echter deze stemming alsnog uit te stellen omdat duidelijk was dat er geen meerderheid voor haar akkoord bestond.

8. Conclusie A-G 4 december 2018, zaak C-621/18, Wightman, ECLI:EU:C:2018:978, punt 62, 81.

9. Conclusie A-G, Wightman, punt 75 en 76 , mede verwijzend naar Hv 16 juni 1998, zaak C-162/96, Racke, ECLI:EU:C:1998:293, punt 59.

10. Conclusie $\mathrm{A}-\mathrm{G}$, Wightman, punt 77 , mijn cursivering. Zie ook punt 84 en 87

11. Zie bijv. conclusie A-G, Wightman, punt 94, 95 en 132

12. Conclusie A-G, Wightman, punt 104. Zie ook de interessante voorbeelden uit de statenpraktijk waar interne gebreken externe effecten hadden in punt 68 e.v., met name waar het Corte Suprema de Justicia de Panamá de Panamese kennisgeving tot uittreding uit Parlacen vernietigde, en Panama als gevolg lid bleef.

13. Conclusie A-G, Wightman, punt 110 en 112. Dit geldt des meer daar het Hof van Justitie in de zaak $R O$ heeft bevestigd dat een lidstaat ook na kennisgeving zijn status als volwaardige lidstaat van de Unie behoudt. Zie conclusie A-G, Wightman, punt 115 en HvJ 19 september 2018, zaak C-327/18 PPU, RO, ECLI:EU:C:2018:733, punt 45.
Ook de doelstellingen van een 'steeds hechter verbond', respect voor de nationale identiteit en de bescherming van EU-burgerschap pleiten voor het in kunnen trekken van een kennisgeving. Een interpretatie die intrekking onmogelijk maakt, kan daarentegen leiden tot een 'gedwongen vertrek' dat juist indruist tegen al deze doelstellingen. ${ }^{14}$ Als laatste blijkt uit het travaux préparatoire dat 'de terugtrekkingsprocedure met name unilateraal is'. 15

De advocaat-generaal concludeert derhalve dat een kennisgeving eenzijdig mag worden ingetrokken. Wel verbindt hij verschillende voorwaarden en grenzen aan dit recht. Zo moet de intrekking geschieden door middel van een formele, tot de Europese Raad gerichte handeling van de lidstaat die de nationale grondwettelijke bepalingen respecteert. Deze intrekking moet plaatsvinden voordat een terugtrekkingsakkoord 'formeel is gesloten'. ${ }^{16}$ De belangrijkste grens is echter dat, gezien de beginselen van goede trouw en loyale samenwerking, lidstaten geen misbruik mogen maken van het recht op intrekking, bijvoorbeeld door 'opeenvolgende kennisgevingen en intrekkingen om betere voorwaarden voor (...) terugtrekking uit de Unie te bedingen'. ${ }^{17}$

\section{Het arrest van het Hof van Justitie}

Het Hof van Justitie oordeelt dat het een soeverein recht is van een lidstaat om een kennisgeving tot uittreding unilateraal in te trekken. Bovendien is het niet toelaatbaar om een lidstaat tegen de eigen wil uit de Unie te zetten. Anders dan de advocaat-generaal begin het Hof van Justitie zijn redenering niet bij het WVV maar bij de constitutionele aard en autonomie van de EU-rechtsorde. ${ }^{18}$ Dit heeft tot gevolg dat de vraag naar intrekking moet 'worden beoordeeld op basis van de Verdragen in hun geheel', waarbij rekening gehouden moet worden met de bewoordingen, de doelstellingen, de context, alsmede de ontstaansgeschiedenis van artikel 50 VEU. ${ }^{19}$ Het uiteindelijke oordeel van het Hof van Justitie berust daarbij met name op de twee doelstellingen van artikel 50 VEU: 'Artikel 50 VEU heeft dus een tweeledig doel, namelijk het verankeren van het soevereine recht van een lidstaat om zich uit de Unie terug te trekken en het opzetten van een procedure voor een ordelijke terugtrekking. ${ }^{20}$

Hierbij legt het Hof van Justitie de nadruk op de eerste doelstelling inzake het soevereine recht van terugtrek-

\footnotetext{
14. Conclusie A-G, Wightman, punt 136.

15. Conclusie A-G, Wightman, punt 139, en verder document CONV 648/03, titel X: Het lidmaatschap van de Unie, 2 april 2003, bijlage II, p. 9, beschikbaar via http://european-convention.europa.eu/pdf/reg/ nl/03/cv00/cv00648.nl03.pdf.

16. Conclusie A-G, Wightman, punt 142, 143147.

17. Conclusie A-G, Wightman, punt 153

18. Wightman, punt $44-45$.

19. Wightman, punt 46

20. Wightman, punt 56 , mijn cursivering.
} 
king, en op daarmee verbonden noties van nationale democratie en zelfbeschikking. ${ }^{21}$ Vervolgens past het Hof van Justitie het soevereine en eenzijdige recht op terugtrekking uit artikel 50 lid $1 \mathrm{VEU}$ analoog toe op intrekking:

'Aangezien de intrekking van de kennisgeving van het voornemen tot terugtrekking niet expliciet is geregeld, gelden voor de intrekking de regels die in artikel 50, lid 1, VEU voor de terugtrekking zijn opgenomen, zodat hiertoe eenzijdig kan worden besloten overeenkomstig de grondwettelijke bepalingen van de betrokken lidstaat.'22

Als gevolg is ook de keuze om een kennisgeving in te trekken een 'soevereine beslissing van die staat om zijn status als lidstaat van de Unie te behouden'. ${ }^{23} \mathrm{Nu}$ was het belangrijkste argument van de Raad en de Commissie tegen een eenzijdig recht gebaseerd op het vereiste van unanieme instemming van de Europese Raad voor uitstel onder artikel 50 lid 3 VEU. Een eenzijdig recht op intrekking zou misbruikt kunnen worden om dit unanimiteitsvereiste te omzeilen. Bij weigering van uitstel zou een lidstaat de facto eenzijdig kunnen verlengen door in te trekken en een nieuwe kennisgeving in te dienen.

Het Hof van Justitie verwerpt dit argument. Volgens het Hof van Justitie is het doel van uitstel enkel om de uittreding te vertragen, terwijl het doel van intrekking behoud van lidmaatschap is. Intrekking verschilt daarmee 'fundamenteel' van uitstel, waardoor de procedure voor uitstel irrelevant is voor intrekking. ${ }^{24}$

Ter verdere ondersteuning van een unilateraal recht op intrekking verwijst het Hof van Justitie naar de doelstellingen van de EU-verdragen om 'een steeds hechter verbond' te creëren en 'de barrières die Europa verdelen te verwijderen', alsmede naar de waarden van vrijheid en democratie, het feit dat de EU stoelt op de vrijwillige deelname, en de juridische plicht om de rechten van EU-burgers te beschermen. ${ }^{25}$ Deze cocktail van soevereiniteit, zelfbeschikking, democratie, EU-integratie en EU-burgerschap leidt tot een verbod om een lidstaat tegen de eigen wil in uit de EU te zetten: 'Daar een staat niet kan worden gedwongen om tegen zijn wil toe te treden tot de Unie, kan hij dus ook niet worden gedwongen om zich tegen zijn wil terug te trekken uit de Unie. ${ }^{26}$

Net als de advocaat-generaal vindt het Hof van Justitie daarnaast verdere steun voor een unilateraal recht op intrekking in de ontstaansgeschiedenis van artikel 50 VEU, met name het belang dat werd gehecht aan 'het vrijwillige en unilaterale karakter' van terugtrekking. ${ }^{27}$

21. Wightman, punt 57

22. Wightman, punt 58

23. Wightman, punt 59.

24. Wightman, punt 60 .

25. Wightman, punt 61-64. Voor burgerschap verwijst het Hof van Justitie naar de plicht tot bescherming zoals vervat in HvJ 2 maart 2010, zaak C-135/08, Rottmann, ECLI:EU:C:2010:104, punt 43.

26. Wightman, punt 65

27. Wightman, punt 68

Anders dan de advocaat-generaal gebruikt het Hof van Justitie artikel $68 \mathrm{WVV}$ vervolgens alleen als een ondersteunend argument voor de EU-rechtelijke interpretatie van artikel $50 \mathrm{VEU} .^{28}$

Op basis van bovenstaande overwegingen oordeelt het Hof van Justitie dat een lidstaat een kennisgeving tot uittreding eenzijdig kan intrekken overeenkomstig zijn grondwettelijke bepalingen zolang het terugtrekkingsakkoord nog niet in werking is getreden of de termijn voor uittreding onder artikel 50 lid 3 VEU nog niet is verlopen. ${ }^{29}$ Het Hof van Justitie stelt slechts twee beperkte voorwaarden aan het gebruik van dit recht. Ten eerste moet de intrekking schriftelijk worden medegedeeld aan de Europese Raad. Ten tweede dient de mededeling 'ondubbelzinnig en onvoorwaardelijk' te zijn. Dit betekent dat de mededeling 'strekt tot bevestiging dat de betrokken lidstaat lid van de Unie blijft onder voormaarden die ongemijzigd blijven wat zijn status als lidstaat betreft, en inhoudt dat de terugtrekkingsprocedure pordt beëindigd'.$^{30}$ Anders dan bij de advocaat-generaal wordt misbruik niet als grens geformuleerd.

\section{Analyse}

Het oordeel van het volledige Hof van Justitie in Wightman is kort en principieel. ${ }^{31}$ De keuze om uit te treden of lid te blijven ligt bij de lidstaat zelf. Dit oordeel berust primair op respect voor nationale soevereiniteit en democratie. Daarnaast dwingen de plicht om de burgerschapsrechten van EU-onderdanen te beschermen en de doelstelling van een steeds hechter verbond tot het maximaal faciliteren van een keuze toch in de EU te blijven.

In de rest van deze bijdrage geef ik een nadere analyse van deze principiële uitspraak. Eerst bespreek ik kort de gevolgen van Wightman voor Brexit. Vervolgens analyseer ik de in het EU-recht vrij unieke erkenning van een schijnbaar absoluut soeverein recht op intrekking. Daarna kijk ik welke grenzen er nu precies gesteld zijn aan dit eenzijdige soevereine recht op intrekking en wie bevoegd is deze grenzen te handhaven. Ik eindig met een korte conclusie.

31. Zo wordt slechts beperkt ingegaan op de tegenargumenten van de partijen en in de literatuur. Zie bijvoorbeeld D. Benrath, 'Bona fide and revocation of withdrawal: how Article 50 TEU handles the potential abuse of a unilateral revocation of withdrawal', EULR 2018, nr. 2, p. 234; A. Sari, 'Reversing a Withdrawal Notification under Article 50 TEU: Can a Member State Change Its Mind?', EULR 2017, nr. 4; P. Ostendorf, 'The withdrawal cannot be withdrawn: the irrevocability of a withdrawal notification under art. 50(2) TEU', EULR 2017, nr. 5, p. 767, of S.C.G. van den Bogaert en A. Cuyvers, 'Brexit: You can't always have what you want', Rechtsgeleerd Magazijn Themis 2018, nr. 6, p. 221 
Het recht op intrekking en consequenties voor Brexit

Met Wightman staat definitief vast dat het VK de kennisgeving eenzijdig mag intrekken en daarmee onder de huidige voorwaarden lid van de EU kan blijven, rebate en opt-outs incluis. Intrekking blijft bovendien mogelijk totdat het terugtrekkingsakkoord in werking is getreden of de (verlengde) termijn onder artikel 50 lid $3 \mathrm{VEU}$ is verlopen. Op het moment van schrijven betekent dit dat het VK tot en met 31 oktober 2019, 22:59:59 uur (VKtijd) de kennisgeving eenzijdig in kan trekken.

Als gevolg hebben het Lagerhuis, en wellicht VK-kiezers, er een optie bij gekregen. Naast een no-deal Brexit of het terugtrekkingsakkoord kan het $\mathrm{VK}$ in de EU blijven. Vooralsnog is er geen grote steun voor deze optie. ${ }^{32}$ Toch heeft de mogelijkheid van intrekking belangrijke gevolgen voor het Brexitproces. Om te beginnen ondermijnt de mogelijkheid van intrekking het belangrijkste argument voor het terugtrekkingsakkoord: dat het akkoord minder erg is dan een no-deal Brexit. Met name remainers kunnen er nu voor kiezen uittreding te blokkeren in de hoop dat uiteindelijk gekozen wordt voor blijvend lidmaatschap, zeker nu een ruime meerderheid in het Lagerhuis tegen een no-deal Brexit is. ${ }^{33}$ Omgekeerd kan het risico van afstel overtuigde Brexiteers er toe brengen voor het terugtrekkingsakkoord te stemmen onder het mom dat een zachte Brexit nog altijd beter is dan geen Brexit. ${ }^{34}$ Het lijkt er echter op dat overtuigde Brexiteers het terugtrekkingsakkoord, met daarin de backstop, net zo erg vinden als geen Brexit. Het toenemende risico op afstel heeft tot nu toe dan ook eerder geleid tot een versterkte roep om een no-deal exit. ${ }^{35}$ Zowel de inmiddels door het Supreme Court illegaal bevonden beslissing van premier Johnson om het parlement voor vijf weken te schorsen (prorogation), alsmede de openlijke speculatie van de Britse regering om in strijd met de European Union (Withdramal) act (No. 6) geen uitstel aan te vragen en daarmee op evident illegale wijze een harde Brexit te forceren, illustreren deze verharding. ${ }^{36}$

\section{Een soevereine renaissance?}

Vanuit constitutioneel perspectief is Wightman met name interessant vanwege de erkenning van een schijnbaar absoluut soeverein recht op intrekking en de nadruk

32. Tijdens de eerste ronde van 'indicative votes' op 27 maart 2019 werd 'optie L' van Joanna Cherry, dat intrekking voorstelde, afgewezen met 184 stemmen tegen 293. Intrekking werd niet eens in stemming gebracht bij de tweede ronde van indicative votes op 1 april 2019.

33. Zie met name de European Union (Withdrawal) (No. 5) Bill en de latere European Union (Withdrawal) (No. 6) Bill die op 9 september 2019 Royal Assent verkreeg en die een harde Brexit bij wet probeert uit te sluiten door de regering te dwingen uitstel aan te vragen als er geen akkoord is op 31 oktober 2019.

34. Zie bijvoorbeeld de draai van aarts-Brexiteer Reese-Mogg onder het motto: 'Half a loaf is better than no Bread.' Beschikbaar via https:// twitter.com/jacob_rees_mogg/status/1110843989605998598.

35. Op 29 maart werd het terugtrekkingsakkoord voor de derde maal afgewezen, ditmaal met een meerderheid van 'slechts' 58 stemmen tegen, ondanks de steun van onder andere Boris Johnson en Reese-Mogg.

36. UK Supreme Court $R$ (on the application of Miller) $v$ The Prime Minister, 24 september 2019, [2019] UKSC 41. op soevereiniteit en zelfbeschikking meer in het algemeen. ${ }^{37}$ Een absoluut soeverein recht lijkt immers in te gaan tegen de orthodoxie waarin soevereiniteit niet kan worden ingeroepen tegen EU-recht. ${ }^{38}$

In Wightman beklemtoont het Hof van Justitie daarentegen juist de uiteindelijke soevereiniteit van lidstaten en het recht op democratische zelfbeschikking inzake terugtrekking. Zo is het besluit van een lidstaat om zich uit de EU terug te trekken 'uitsluitend afhankelijk van zijn soevereine wil'. ${ }^{39}$ Een van de doelen van artikel 50 $\mathrm{VEU}$ is om dit 'soevereine recht' op terugtrekking veilig te stellen. Het is dan ook het 'soevereine karakter' van het recht op terugtrekking dat uiteindelijk ten grondslag ligt aan het oordeel dat de kennisgeving eenzijdig ingetrokken kan worden. ${ }^{40}$ Intrekking is immers 'een soevereine beslissing van die staat om zijn status als lidstaat van de Unie te behouden'. ${ }^{41}$

Op zich is deze nadruk op soevereiniteit in overeenstemming met het doel achter artikel 50 VEU om de uiteindelijke soevereiniteit van lidstaten (symbolisch) te erkennen. ${ }^{42}$ Daarnaast dient het specifieke karakter van terugtrekking benadrukt te worden. Het al dan niet beëindigen van EU-lidmaatschap is een ander soort beslissing dan het al dan niet respecteren van EU-recht tijdens lidmaatschap. Tegelijkertijd is de expliciete erkenning van een vrijwel absoluut soeverein recht een unicum binnen EU-recht. Zoals hieronder nader wordt besproken formuleert het Hof van Justitie immers slechts enkele beperkte, formele voorwaarden voor het gebruik van het recht op intrekking, terwijl zelfs op zeer gevoelige nationale terreinen zoals belastingen, sociale zekerheid, nationale veiligheid of buitenlands beleid de standaardbenadering is dat nationale bevoegdheden binnen de grenzen van EU-recht uitgeoefend moeten worden. ${ }^{43}$ Dit gegeven bracht de huidige president van het Hof van Justitie in 1990 al tot de conclusie dat er '(...) simply is no nucleus of sovereignty that the Mem-

37. Zie ook 'Editorial: The European Court of Justice and the politics of Brexit - the Wightman judgment' European Law Review 2019, nr. 1, p. 2.

38. Zie naast klassiekers als HvJ 15 juli 1964, zaak 6/64, Costa/E.N.E.L., ECLI:EU:C:1964:66 of HvJ 26 februari 2013, zaak C-399/11, Melloni, ECLI:EU:C:2013:107 voor de leidende studies op dit punt o.a. N. MacCormick, Questioning Sovereignty: Law, State and Nation in the European Commonwealth, Oxford: Oxford University Press 1999 en N. Walker (red.), Sovereignty in Transition, Oxford: Hart Publishing 2006.

39. Wightman, punt 50

40. Wightman, punt 57

41. Wightman, punt 59

42. Zie onder andere C. Hillion, 'Accession and Withdrawal in the Law of the European Union', in: A. Arnull en D. Chalmers (red.), The Oxford handbook of European Law, Oxford: Oxford University Press 2015, p. 126 of A. Cuyvers, 'Artikel 50 VEU en Brexit: de juridische contouren voor een politiek drama', NtEr 2016/7, p. 221. Voor een nadere analyse inzake soevereiniteit zie A. Cuyvers, The EU as a Confederal Union of Sovereign Member Peoples - Exploring the potential of American (con)federalism and popular sovereignty for a constitutional theory of the EU (diss. Leiden), 2013.

43. Zie bijvoorbeeld reeds HvJ 10 juli 1984, zaak C-72/83, Campus Oil, ECLI:EU:C:1984:256, HvJ 24 november 1998, zaak C-274/96, Bickel en Franz, ECLI:EU:C:1998:563, HvJ 12 juli 2005, zaak C-403/03, Schempp, ECLI:EU:C:2005:446 of HvJ 22 december 2010, zaak C-208/09, Sayn-Wittgenstein, ECLI:EU:C:2010:806. 
ber States can invoke, as such, against the Community'. ${ }^{44}$ Daar de lidstaat op het moment van intrekking nog steeds lid is, en wil blijven, zou onder deze lijn ook het recht om in te trekken binnen de grenzen van het EUrecht uitgeoefend moeten worden.

Alleen al door de erkenning van een soeverein recht vormt Wightman daarmee een interessante ontwikkeling in de discussie omtrent de EU en soevereiniteit. Toch moet men Wightman niet te ver voeren. Gezien de unieke aard en context van uittreding ligt het niet voor de hand Wightman ook buiten de context van uittreding toe te passen, al kan de zaak wellicht ook relevant zijn in de context van toetreding of situaties waarin lidstaten zich opdelen, en wellicht interne, soevereine keuzes over EU-lidmaatschap gemaakt moeten worden.

Grenzen aan het recht op intrekking?

Zelfs het soevereine recht op intrekking is blijkbaar niet geheel onbegrensd, al formuleert het Hof van Justitie slechts twee beperkte voorwaarden. De intrekking moet 'schriftelijk' gebeuren en moet 'ondubbelzinnig en onvoorwaardelijk' zijn. ${ }^{45}$ De vraag is wat deze twee voorwaarden betekenen, of er echt geen verdere grenzen zijn, waaronder misbruik van recht, en wie deze grenzen mag interpreteren en handhaven.

\section{- Schriftelijk, ondubbelzinnig en onvoormaardelijk}

Het vereiste dat intrekking schriftelijk dient te geschieden zal allicht niet tot veel discussie leiden. Wel kan nog wel gevraagd worden wat er gebeurt als de intrekking mondeling gebeurt maar de Europese Raad de intrekking toch als rechtsgeldig behandelt. Zou het Hof van Justitie dan kunnen oordelen dat er nooit een rechtsgeldige intrekking is geweest, en het $\mathrm{VK}$ derhalve toch is uitgetreden? ${ }^{46}$

Ook het vereiste dat de intrekking 'ondubbelzinnig en onvoorwaardelijk' moet zijn lijkt relatief helder. Toch zijn dit geen scherp gedefinieerde juridische criteria en is ook niet duidelijk wat de juridische basis voor deze voorwaarden is. ${ }^{47}$ De ratio lijkt tweeledig. Ten eerste dient het, mede gezien de enorme belangen, glashelder te zijn of er is ingetrokken of niet. De rechtszekerheid zou niet gebaat zijn bij een vaag of voorwaardelijk geformuleerde intrekking waarover onenigheid kan ontstaan. Ten tweede moet het met een intrekking ook echt gedaan zijn. Het Hof van Justitie koppelt intrekking expliciet aan beëindiging van de intrekkingsprocedure. ${ }^{48}$ Intrekking mag derhalve geen tussenstap vormen, bijvoorbeeld door aanvullende concessies te eisen inzake vrij verkeer van personen of financiële regulering voor-

44. K. Lenaerts, 'Constitutionalism and the many faces of Federalism' The American Journal of Comparative Law 1990, nr. 38, afl. 2, p. 220

45. Wightman, punt 74

46. Zie nader par. 'Interpretatie en handhaving van de grenzen aan het recht op intrekking' hierna over de rol van het Hof van Justitie.

47. Met dank aan de reviewers kan opgemerkt worden dat het ook onder Nederlands recht vereist is dat een stelling of vordering in een procedure 'ondubbelzinnig en onvoorwaardelijk' wordt ingetrokken. Dit benadrukt de meer formele, procedurele aard van deze voorwaarde, die eerder gericht lijkt op het garanderen van duidelijkheid voor alle partijen dan het stellen van een inhoudelijke grens aan het recht op intrekking.

48. Wightman, punt 74 dat definitief wordt ingetrokken. Gezien deze doelen lijkt het een logische interpretatie dat een intrekking ondubbelzinnig moet stellen dat de lidstaat de kennisgeving definitief en onvoorwaardelijk intrekt en daarmee het huidige lidmaatschap voortzet. Een mooie juridische en conceptuele puzzel die dan overblijft is of de lidstaat ook de intrekking weer kan intrekken. Enerzijds lijkt het eenzijdige en soevereine karakter van intrekking te pleiten voor de mogelijkheid van een intrekking van de intrekking. Anderzijds dient de intrekking volgens het Hof van Justitie ertoe te leiden 'dat de terugtrekkingsprocedure wordt beëindigd'. ${ }^{49}$ Als een intrekking de terugtrekkingsprocedure al heeft beëindigt dan heeft een intrekking van de intrekking, zelfs indien theoretisch mogelijk, niet veel zin, en rest slechts een nieuwe kennisgeving met een nieuwe termijn van twee jaar.

Naast de intrekking van de intrekking kan echter ook de vraag gesteld worden wat er gebeurt als de intrekking van de kennisgeving onder national recht vernietigd zou worden. ${ }^{50}$ Neem bijvoorbeeld het geval waar de premier de kennisgeving in zou trekken zonder de door Miller vereiste instemming van het Lagerhuis. Zeker wanneer een dergelijke vernietiging ex tunc zou werken, zou beargumenteerd kunnen worden dat er onder nationaal constitutioneel recht nooit een intrekking is geweest en dat derhalve de kennisgeving onder artikel 50 lid 1 VEU met terugwerkende kracht herleeft. Wanneer in de tussentijd de datum voor uittreding is verstreken, zou het gevolg kunnen zijn dat het VK met terugwerkende kracht en zonder akkoord zou zijn uitgetreden. Aan de andere kant kan men stellen dat een dergelijke interne complicatie niet tegengeworpen kan worden aan de andere lidstaten, hoewel de vernietiging van de Panamese terugtrekking uit Parlacen schijnbaar wel extern effect had. ${ }^{51}$ Indien vernietiging onder nationaal recht kan leiden tot intrekking, rijst vervolgens natuurlijk de vraag wat de gevolgen van een nationale vernietiging van de intrekking van de intrekking dan zouden zijn.

- Herhaalde kennisgeving, misbruik van recht en de grenzen van een soeverein recht

Zoals genoemd vreesden de Commissie en de Raad dat een unilateraal recht op intrekking misbruikt kon worden om het unanimiteitsvereiste voor verlenging te omzeilen. De advocaat-generaal adresseerde dit risico door misbruik van het recht op intrekking te verbieden. ${ }^{52}$ Het Hof van Justitie noemt misbruik daarentegen niet als een grens aan intrekking. De vraag is hoe dit stilzwijgen te interpreteren. Gezien de nadruk van het Hof van Justitie op het eenzijdige en soevereine karakter van intrekking lijkt het aan de ene kant logisch dat het recht op intrekking absoluut is en niet misbruikt kan worden. Zowel het besluit om de EU te verlaten als het besluit

49. Wightman, punt 74

50. Zie op dit punt ook de argumenten van de A-G inzake de mogelijke vernietiging van de kennisgeving in plaats van een intrekking.

51. Conclusie A-G, Wightman, punt 69 en 70, en de uitspraak van de Panamese Corte Suprema de Justicia van 2 februari 2012, https:// vlex.com.pa/vid/accion-inconstitucionalidad-sala-pleno-375091942? _ga=2.13901559.115975578.1539971406-1717765214.1539971406.

52. Conclusie A-G, Wightman, punt 153. 
om toch in de EU te blijven zijn immers eenzijdige soevereine rechten, zodat het volledig aan het democratische besluitvormingsproces in de lidstaat zelf is om te besluiten over kennisgeving en intrekking.

Aan de andere kant vormt het verbod op misbruik van recht nu eenmaal een algemene doctrine van EUrecht. ${ }^{53}$ Dit zou betekenen dat het verbod op misbruik gewoon van toepassing is op intrekking, ook al heeft het Hof van Justitie dit niet expliciet benoemd. Als gevolg zou een lidstaat geen beroep mogen doen op het recht op intrekking als intrekking objectief het beoogde doel van blijvend lidmaatschap toch niet zou bereiken, bijvoorbeeld omdat naast een ondubbelzinnige en onvoorwaardelijke geformuleerde intrekking per direct weer een kennisgeving tot uittreding wordt gedaan, en intrekking subjectief het wezenlijk doel zou hebben om een ongerechtvaardigd voordeel te bereiken, zoals bijvoorbeeld een uitstel van de tweejaarstermijn waar de Europese Raad dit niet wilde geven. ${ }^{54}$

Of, en in welke gevallen, het recht op intrekking misbruikt kan worden is daarmee nog niet zeker. Tegelijkertijd moet benadrukt worden dat in de praktijk niet al te veel verwacht kan worden van een juridische grens aan een politieke keuze als uittreding of intrekking. ${ }^{55}$ Ook zal de sanctie op misbruik eerder politiek zijn dan juridisch: een lidstaat die te kwader trouw intrekt, zal bij een hernieuwde kennisgeving weinig bereiken aan de onderhandelingstafel.

- Interpretatie en handhaving van de grenzen aan het recht op intrekking

Aangezien de intrekking gericht is tot de Europese Raad lijkt het logisch dat de eerste interpretatie en handhaving van de voorwaarden voor intrekking bij de Europese Raad ligt. Hoewel de kans gering is, rijst hiermee de vraag wat de juridische situatie is wanneer de Europese Raad, of eventueel een andere EU-instelling of individuele lidstaat, van mening is dat de intrekking niet aan de voorwaarden voldoet, en dat derhalve niet rechtsgeldig is ingetrokken. Enerzijds kan men stellen dat, aangezien er volgens het Gerecht geen formele acceptatie van de kennisgeving tot uittreding nodig is, er ook geen formele acceptatie of afwijzing van de intrekking

53. Zie o.a. HvJ 28 juli 2016, zaak C-423/15, Kratzer, ECLI:EU:C:2016:604, punt 37-42, HvJ 13 maart 2014, zaak C-155/13, SICES, ECLI:EU:C: 2014:145, punt 29, HvJ 12 mei 1998, zaak C-367/96, Kefalas, ECLI:EU:C:1998:222, punt 20; HvJ 23 maart 2000, zaak C-373/97, Diamantis, ECLI:EU:C:2000:150, punt 33, en HvJ 21 februari 2006, zaak C-255/02, Halifax, ECLI:EU:C:2006:121, punt 68

54. Daarbij is van belang dat er geen sprake is van de vereiste subjectieve intentie tot misbruik als voor de intrekking ook een andere verklaring kan bestaan dan de loutere verkrijging van bijvoorbeeld een geweigerd uitstel. Er zou met name sprake van misbruik kunnen zijn als het 'louter kunstmatige karakter' van een intrekking aangetoond zou kunnen worden, bijvoorbeeld op basis van het nationale politieke debat. Zie o.a. HvJ 21 februari 2006, zaak C-255/02, Halifax, ECLI:EU:C:2006:121, punt 75, of HvJ 22 december 2010, zaak C-103/09, Weald Leasing, ECLI:EU:C:2010:804, punt 30 en HvJ 14 december 2000, zaak C-110/99, Emsland-Stärke, ECLI:EU:C:2000:695, punt 53 en 58.

55. Zie voor een uitgebreidere bespreking van de relatieve invloed van het recht op majeure politieke beslissingen als Brexit ook reeds S.C.G. van den Bogaert en A. Cuyvers, 'Brexit: Over \& Out?' NJB 2016, nr. 36, p. $2666-2677$. nodig is. ${ }^{56}$ Een afwijzing zou dan een rechtsfeit zijn, een soort naakte constatering dat de intrekking niet aan de formele vereisten voldoet en dat er derhalve niet is ingetrokken. Het rechtsgevolg van deze constatering (een harde exit) zou dan niet voortvloeien uit de afwijzing maar direct uit artikel 50 VEU. Gezien de onomkeerbare consequenties van een weigering, de omstandigheid dat weigering een interpretatie eist en de rechtsonzekerheid die uit onenigheid over de status van de intrekking zou voortvloeien, lijkt het echter verkieslijker om de weigering van een intrekking wel als een formeel besluit van de Europese Raad te zien. Een eventuele weigering van de intrekking zou dan een onder artikel 263 Verdrag betreffende de werking van de Europese Unie (VWEU) voor beroep vatbare rechtshandeling zijn. ${ }^{57}$ Als gevolg kan de uittredende lidstaat een actie tot nietigverklaring instellen tegen het weigeringsbesluit van de Europese Raad, waarmee de uiteindelijke interpretatie van de grenzen aan het recht op intrekking aan het Hof van Justitie blijft. Gezien de nadruk in Wightman op het verbod een lidstaat tegen de eigen wil in uit de EU te zetten, lijkt het daarbij aannemelijk dat het Hof van Justitie enkel een weigering zou accepteren als hiervoor zeer overtuigende gronden bestaan.

$\mathrm{Nu}$ er geen expliciete procedure is voor het beoordelen van een intrekking dient een besluit tot weigering onder artikel 15 lid 4 VEU vermoedelijk met unanimiteit genomen te worden. Daarbij komt dan weer de vraag op of de intrekkende lidstaat mee mag stemmen, of dat, parallel aan artikel 50 lid 3 VEU, bepleit kan worden dat de uittredende lidstaat niet mee mag stemmen over de eigen intrekking. ${ }^{58}$ Enerzijds is het afpakken van stemrecht natuurlijk bijzonder ingrijpend, en daarmee lastig te rechtvaardigen zonder expliciete basis. Anderzijds zou, gezien het unanimiteitsvereiste voor afwijzing, het recht op meestemmen over de eigen intrekking betekenen dat een intrekking nooit geweigerd kan worden. Daarnaast lijkt het, gezien het uitgangspunt dat een lidstaat niet tegen de eigen wil uit de EU gezet kan worden, logisch om aan te nemen dat een intrekking vermoed wordt rechtsgeldig te zijn tenzij de Europese Raad unaniem oordeelt dat de intrekking niet rechtsgeldig is. De omgekeerde regel zou immers iedere lidstaat een veto geven over intrekking, wat in strijd is met het door het Hof van Justitie geformuleerde beginsel dat een

56. Gerecht 26 november 2018, zaak T-458/17, Shindler, ECLI:EU:T: 2018:838.

57. De weigering is immers een handeling van een instelling die beoogt bindende rechtsgevolgen in het leven te roepen die het VK in zijn belangen raken. Dit verschilt van de ontvangst van de kennisgeving door de Europese Raad die volgens het Gerecht niet kwalificeerde als een aanvechtbare rechtshandeling. Zie o.a. reeds HvJ 11 november 1981, zaak C-60/81, IBM, ECLI:EU:C:1981:264, punt 9 en Gerecht 26 november 2018, zaak T-458/17, Shindler, ECLI:EU:T:2018:838. Een wat vergezochte maar interessante complicatie zou optreden wanneer de weigering van de intrekking door de Europese Raad zou leiden tot een harde exit, en de vraag gesteld kan worden of de inmiddels uitgetreden lidstaat nog ontvankelijk is in een procedure onder art. 263 VWEU, en of een vernietiging van de weigering van de intrekking betekent dat de staat met terugwerkende kracht altijd lidstaat is gebleven.

58. Ter verdere ondersteuning kan een parallel getrokken worden met art. 7 VEU waar de lidstaat ook niet mee mag stemmen. 


\section{Conclusies en bredere impact Wightman}

Het recht op intrekking zal misschien nooit gebruikt worden. Toch is de expliciete erkenning van een soeverein recht op intrekking door het voltallige Hof van Justitie van belang, zowel voor Brexit als voor het construeren van de constitutionele aard van de EU.

Hoewel meerdere vragen resteren omtrent de exacte aard van het recht op intrekking en de EU-rechtelijke grenzen aan het gebruik van dit recht, is de principiële positie van het Hof van Justitie overtuigend. Natuurlijk kan een eenzijdig recht op intrekking tot complicaties leiden. Ook valt de frustratie met het VK te begrijpen, net als de angst dat een halfslachtige keuze om in de EU te blijven op lange termijn een negatief effect zal hebben op de slagvaardigheid van de Europese integratie. Toch valt moeilijk in te zien hoe een Unie die opgericht is om te verbinden, en die landen heeft samengebracht die elkaar herhaaldelijk op het slagveld hebben bestreden, niet over een kennisgeving tot uittreding heen zou kunnen stappen. Ook de bescherming van het Unieburgerschap van de burgers van de uittredende lidstaat is een overtuigend argument, net als de constatering dat de EU verplicht is om een nationale democratische keuze om lid te blijven te respecteren. Toegegeven, in de context van Brexit kunnen dit dure principes zijn. In een Unie gevestigd op de waarden van vrijheid en democratie mogen deze kosten echter geen reden zijn de eigen funderende principes opzij te zetten. 